\title{
Policy of development from outskirts: analysis of budgeting for village funds in Indonesia
}

\author{
Marlan Hutahaean ${ }^{1}$ \\ \{marlamhutahaean1965@gmail.com ${ }^{1}$ \} \\ Universitas HKBP Nommensen Medan, Indonesia ${ }^{1}$
}

\begin{abstract}
This article wants to explain the government policy that has been done in building the village, especially budgeting for village funding policy in Indonesia. By using a qualitative approach and primary and secondary data, this research found that VF policy has not been able to accelerate the process of village development. Based on these findings, the policy recommendations are proposed: firstly, it is necessary to improve the implementation of technical guidance related to program choice and budget formulation for village apparatus. Secondly, there is a need for synergy between village apparatus, private sector and universities in conducting studies on village issues.
\end{abstract}

Keywords: Public policy, village development, village apparatus, program priority, budgeting

\section{Introduction}

This paper wants to explain the village development policies, especially the Village Fund (VF) policy. The focus of the study is that the implications of the VF policy on accelerating village development. Study locomotives in several villages in Indonesia. The argument put forward that the VF policy has not been able to act as a channel for accelerating village development.

Development, including village development is a process of change to a better situation. The problem is that village development itself is not absolutely successful in the hands of the authorities and villagers, but is influenced by many other factors. Village development also has a risk of failure, as is the case with business. This is in line with Bernstein, Fafchamps, as quoted by Anderson [1], that Development is an inherently risky business, as evidenced by the history of interventions by many would-be actors.

Since the beginning of independence, the government has carried out various policies that try to make the village develop, so that its people do not urbanize. The various policies referred to were not only carried out in one sector but multi-sector, such as oil sprinkling policies in the Old Order era, Indonesian military entering villages and lagging villages in the New Order era, and so on.

Unfortunately, these policies have not been able to make villages in Indonesia progress and develop. During the Reformation period, the government established the VF policy. The assumption is that the problem of village development has been related to budget constraints in the village. Thus, through the availability of the village budget it is expected that the development can occur. The implication of VF finally is the reduction of poverty in the village. 
Unfortunately, village officials lack the ability to manage existing budgets and even bias their use. Some cases that show that there is irregularity in the use of VF are punished by several elements of the village apparatus because of the misuse of the budget. In addition, village assistants who are specifically recruited to assist village officials in managing VF are also mostly less reliable. In fact, they often do not provide solutions, but hinder the planning and implementation of the program. Their recruitment pattern is the main cause. Those recruited as facilitators in the village in managing VF are not based on competence, but rather on political nuances. In the early days of recruitment, those chosen as companions in the village were prioritized as affiliates or at least sympathizers of certain political parties. This is in line with what Palmer said. Palmer [2], emphasizes that three things are a problem when introducing and implementing programs in developing countries. The three things referred to are the main requirements and must be of great concern, namely, technical staff and equipment, cultural background and politics.

On the other hand, the lack of impact of the VF program in accelerating village development is due to the lack of synergy between village programs and district and / or subdistrict programs. There is a tendency that programs from these three levels run independently. Or at least the synergy between the program through VF with the sub-district program is less synergistic. In fact, even though it originates from a different budget, if the two programs or even with synergistic districts, will have a major impact on rural development. Moreover, in order to achieve the Sustainable Development Goals (SDGs), these three levels must form and implement a synergistic program. For this purpose, the Multi-level Governance theory in the village, sub-district and district development process becomes a necessity. The theory produced by Hooge and Marks [3], in 1990 in order to integrate Europe, argues that state centric and collective decision making can no longer be maintained to Europe unity and must be replaced with integration through Multi-Level Governance. Multi-Level Governance theory emphasizes that the implementation of policy making and authority must involve various actors at the government, local, sub-national, national or supra national levels.

Using this theory, the three levels, village (micro level), sub-district (meso level), and district (macro level) must discuss together in formulating programs that can accelerate village development. Meanwhile, viewed from the village level, the RT / RW (micro level), Hutment (Kampung) (meso level) and Village (macro level) also have to sit together when discussing village programs. Why are villages central to development in sub-districts or districts? Because, if we want to build the district or sub-district, we actually build the village. When the villages have developed, then the sub-district or district automatically develops. This is really the meaning of building from the periphery or from behind it.

Furthermore Saraceno[4], as quoted by Midmore[5], distinguishes two key features of rural development: a reversal of migration flows (disguised by declining fertility in both rural and urban regions), and the greater spatial diffusion of production and exchange, even though the disadvantage (low incomes, poor mobility and access to services) for most remains a serious problem. That means how to make village development work well, it is more focused on the livelihoods of the population. Because villagers are more dominant in livelihoods from the agricultural sector, the support of programs in agriculture must be a priority. In addition to suppressing the increase in population through fertility and so that the productive age population does not urbanize. Because the population of productive age in the village is the spearhead of the village development itself. 


\section{Methodology}

The method used in analyzing data is qualitative methods and public policy analysis. The qualitative method is used because it can describe more in the data collected, both primary and secondary data. Then, the method of public policy analysis is used to analyze and describe the root causes of the emergence of VF policies, formulation, adoption, implementation, monitoring and evaluation. The data used for analysis are primary data through interviews with resource persons from the regional apparatus, and secondary data from books, previous research results, journals, online media, comments from relevant experts, bureaucrats, party elites, conference results and website.

\section{Result and Discussion}

Village funds have been regulated in Government Regulation Number 60 of 2014 concerning Village Funds sourced from the National Budget. Article 1 paragraph (2) states that Village Funds are Funds sourced from the State Budget of Revenues and Expenditures intended for Villages that are transferred through the District / City Regional Revenue and Expenditure Budget and used to finance government administration, development implementation, community development, and empowerment the community. Furthermore, in Article 6 it is stated that the Village Fund is transferred through the district / city APBD to be subsequently transferred to the Village APB.

Furthermore, the Ministry of Village, Development of Disadvantaged Region and Transmigration argues that the VF policy is aimed at changing the paradigm of the village from the one that has placed the village as the object of development into a village as a subject of development. Villages as objects of development mean that the government has a dominant role in directing its development. Conversely, the village as the subject of development is defined as the village itself with the community directing its development. Through such a paradigm change, it is expected that the village will be faster in development by involving community participation in the development process.

Changes made by the government not only at the paradigm level, but also in terms of the development budget. Village development budgets that have so far been integrated with the district budget, whose realization cannot be ascertained because depending on the priorities and capabilities of the district budget, experience significant changes. Villages as stipulated in Law No. 6 of 2014 has its own budget which is directly sourced from the State Budget $(\mathrm{APBN})$, even though its distribution remains through the APBD. After the issuance of Government Regulation No. 60 concerning Village Funds, hence from 2015-2018, VFs that have been allocated through the APBN to tens of thousands of villages in Indonesia are as follows: in 2015 amounting to Rp. 20.67 Trillion distributed to 74,093 villages, the average absorption capacity was $82,72 \%$. In 2016 , Rp.46.98 Trillion was distributed to 74,754 villages with an average absorption of $97.65 \%$. The year 2017 amounted to IDR 60 Trillion which was distributed to 74,910 villages with an average absorption capacity of $98.26 \%$. In $2018 \mathrm{Rp} .60$ Trillion was distributed to 74,958 villages.

After running for three and a half years, the government claimed that the VF policy had gone well. Data in 2018 shows that VF, which was rolled out since 2015, has successfully implemented various programs as shown in the following table. 
Table 1. Use of Village Fund Budget for Economic Support Programs2015-2017

\begin{tabular}{rlr}
\hline No. & \multicolumn{1}{c}{ Program Type } & \multicolumn{1}{c}{ Amount } \\
\hline 1. & Development of Village Road & $123.145 \mathrm{Km}$ \\
2. & Development of Bridge & $791.258 \mathrm{M}$ \\
3. & Development of Village Market & 5.220 Unit \\
4. & Development of Village Enterprises & 26.070 Unit \\
5. & Development of Boat Mooring & 2.882 Unit \\
6. & Development of Water Reservoir & 1.927 Unit \\
7. & Development of Irrigation & 28.091 Unit \\
8. & Development of Sport Facilities & 3.004 Unit \\
\hline
\end{tabular}

Source: Ministry of Village, Development of Disadvantaged Region

In addition to development programs for economic support, programs carried out through AVF are related to programs to improve the quality of life of rural communities. Table 2 below shows the success of the program.

Table. 2. Use of Village Fund Budget for Programs Improving the Quality of Life of Village Communities in 2015-2017

\begin{tabular}{clr}
\hline No. & \multicolumn{1}{c}{ Program Type } & \multicolumn{1}{c}{ Amount } \\
\hline 1. & Development of Ground Retainer & 65.918 Unit \\
2. & Development of Clean Water & 32.711 Unit \\
3. & Development of Toilet & 108.486 Unit \\
4. & Development of Maternity Center & 5.314 Unit \\
5. & Development of Drainage & $38.217 \mathrm{Km}$ \\
6. & Development of Early Chilhood Education & 18.072 Unit \\
7. & Development of Integrated Health Service & 11.424 Unit \\
8. & Development of Well & 30.212 Unit
\end{tabular}

Ministry of Village, Development of Disadvantaged Region and Transmigration, March, 5, 2018

Indeed recent study shows that the practice of using the Village Fund can improve community welfare and change the village development paradigm, because it encourages the relationship between state and village. The government claims there are two groupings of success of the AVF program, first, increased village status and poverty reduction yang shown through the alleviation of 9,975 disadvantage villages (IDM 2015-2016), exceeding the target of the 2015-2019 RPJMN of 5,000 villages and reducing the average number of poor people by $1.33 \%$. Second, community welfare and economic growth shown through improved condition of road infrastructure $(81.9 \%)$, housing infrastructure $(27 \%)$, health services (43.9\%), education services $(27.8 \%)$, direct labor absorption $(94.4 \%)$, Villlageent reprises capital (30.8\%), increased community participation in $91.8 \%$ of villages and increased governance competence in $89.6 \%$ of villages and $75 \%$ direct employment, $50 \%$ of primary 
livelihoods and $33.3 \%$ business productivity increase. This success according to the government is also in line with the findings of the Gadjah Mada University Center for Rural and Regional Studies in North Kalimantan Province and 5 districts (Ponorogo, Bantul, Klaten, Sintang and Sidoarjo). community participation and the growth of social capital.

Furthermore, to accelerate the achievement of objectives, in 2018 the government changed the VF allocation pattern from before. VF in 2015-2017 is allocated for basic allocation (in the framework of justice) by $90 \%$ and $10 \%$ allocated based on the number of villagers $25 \%$, the average poor people in the village $35 \%$, the village area $10 \%$, geographical location $30 \%$. As for VF in 2018, the allocation is for basic allocation (in the framework of justice) of $77 \%, 3 \%$ of affirmation allocations (very low levels of backwardness and high poverty), and $20 \%$ allocated based on the village population of $10 \%$, the average poor in the village $50 \%$, village area $15 \%$, geographical location $25 \%$.

In addition to changes in VF allocations, in 2018 the government also made changes to the priority of budget use. According to Minister of Village's Regulation No. 19 Year 2017 about Priority of Village Fund Utilization in 2018 "The Village Fund can be used for the implementation of programs / activities for village development, community empowerment, and inter-sectoral activities agreed through the village meeting then published in the public space"

Village Development for providing Basic Facilities, Village Economic Facility, Environmental Conservation, Natural Disaster Management. Meanwhile, Community Empowerment: Improving Quality of Basic Social Service Facilities, Local Resource Management, Productive Economic Business Management, Capacity Building for Disaster, Environmental Conservation and Strengthening Democratic Village Governance. Whereas inter-sectoral activities related to support programs and activities such as Developing Village Flagship Products, Water Reservoirs, Village Enterprises (BUM Desa) or Holding BUM Desa and Sport Facilities.

Success claims presented by the government actually do not mean that VF policies do not experience problems. Various problems arise in the implementation of this VF policy. The Corruption Eradication Commission found at least 14 problems divided into four aspects. These four aspects are aspects of institutional regulation, aspects of governance, aspects of supervision, and aspects of human resources.

Issues in aspects of institutional regulation can be seen from the incomplete regulations and technical guidelines for the implementation of village finance. Then, there is the potential for overlapping authority between the Ministry of Villages, Development of Disadvantaged Region and Transmigration with the Directorate General of Village Government Ministry of Home Affairs. In addition, there are three ministries that handle it, namely the Ministry of Home Affairs as the supervisor, the Ministry of Finance as the distributor of funds, and the Ministry of Village, Development of Disadvantaged Region and Transmigration as fund users. If one of the institutions experiences problems, it will certainly result in disruption of the work of other institutions. For example, if the Ministry of Finance is late in channeling funds, the Ministry of Villages, Disadvantaged Regions and Transmigration are hampered from utilizing funds.

The formula for distributing village funds as stipulated in Government Regulation No. 22 of 2015 is not transparent enough and is only based on equity. Then, the arrangement of the distribution of fixed income for the village apparatus from AVF as regulated in PP No. 43 of 2014 is less fair. In addition, the obligation to prepare village accountability reports is inefficient due to regulatory provisions and overlapping. That means that village fund 
allocation cannot only focus on aspects of equity. The village needs one with another village can be different, both in terms of geography and in terms of the needs of the village itself.

While from the management aspect, there are five issues, namely, the time frame of village budget management sites is difficult to be followed by the village, the standard price unit of goods or services that is used as a reference for villages in preparing APBDesa is not yet available, and the transparency of APBDesa's use and accountability plan is still low. . Accountability reports made by the village have not followed standards and are prone to manipulation. Finally, the draft APBDesa does not fully describe the needs of the village.

Furthermore, from the aspect of supervision, there are three potential problems, such as the effectiveness of the regional inspectorate in supervising financial management in the village is still low, the public complaint channel is not managed properly by all regions and the scope of evaluation of the supervision carried out by the sub-district head is unclear. Finally, from the aspect of human resources, there is a potential problem, that is, assisting personnel have the potential to commit corruption because they exploit the weakness of village officials.

Another problem that should be of concern to the government is how in the process of preparing village programs synergizing the Village program (micro level), with the SubDistrict program (meso level), and the District program (macro level). The synergy of the three would certainly make village development more successful and targeted. So far, these three levels have not yet made synergies in program preparation. The proof is that there are programs that overlap between villages and districts, such as the use of a budget for the same job.

\section{Conclusion}

Village Fund Policy as stated in Law No. 6 of 2016 concerning Villages, which subsequently carried out through Government Regulation No. 60 of 2014 concerning Village Funds sourced from the State Budget, which was subsequently amended through Government Regulation No. 22 of 2015, has shown that the government has a high willingness to develop villages in Indonesia. Advancing the village means reducing poverty, which will thus improve its welfare.

Planning and implementing village development programs using village funds is not an easy thing. That said, because the village itself experiences the complexity of the problem. The lack of resource and equipment capabilities must become the government's main concern. In addition, the focus of the village fund program should be more directed to sectors that have been the source of life for villagers. The allocation of village funds to the agricultural and / or livestock sector should be improved rather than just the construction of road, bridge, sanitation infrastructure, and so on. Indeed infrastructure is important in supporting the entry and exit of commodities from the village. However, the allocation of village funds to strengthen the agricultural and / or livestock sector such as providing loans or subsidies must be a top priority.

Furthermore, because in the village the ability of community resources is very limited, so besides the presence of village or sub-district facilitators, it is time to increase synergy between the government, universities and the private sector in managing village funds. Universities and the private sector, in addition to having reliable resources, also have experience in managing finance, programs and program implementation. 


\section{Acknowledgments}

The Author would like to thank to the Public Administration Department, Faculty of Social and Political Sciences, and Master of Administrative Science, Post Graduate Program, HKBP Nommensen University that has funded this research.

\section{References}

[1] J. R. Anderson, "Risk in Rural Development: Challenges for Managers and Policy Makers," Agric. Syst., vol. 75, pp. 161-197, 2003.

[2] C. F. Palmer, "Systems Analysis and Model Building Techniques in Rural Development," Proj. Manag., vol. 2, no. 4, pp. 232-239, 1984.

[3] G. Marks, Hooghe, Liesbet, and B. K, "European Integration from the 1980s: State Centric v. Multi-Level Governance," J. Common Mark. Stud., vol. 34, no. 3, pp. 341378, 1996.

[4] P. Midmore, "Rural Policy Reform and Local Development Programmes: Appropriate Evaluation Procedures," J. Agric. Econ., vol. 49, no. 3, pp. 409-426, 1998.

[5] E. Saraceno, "Recent trends in rural development and their conceptualisation," $J$. Rural Stud., vol. 10, no. 4, pp. 321-330, 1994. 